ngetahuan dan Manajerial.

\title{
Penguatan Pengetahuan dan Manajerial Mahasiswa Melalui \\ Maha Bidang Komunikasi
}

\author{
Dra. Frida Kusuma Astuti, M.Si ${ }^{1)}$ \\ Jamroji, S.Sos ${ }^{2)}$
}

\begin{abstract}
Akhir-akhir ini bidang komunikasi menjalani perkembangan yang luar biasa dan sudah menjadi ladang bisnis yang menjanjikan. Pertimbangan ukurannya adalah pentingnnya keterampilan komunikasi dalam kehidupan baik sektor formal seperti karir, bisnis, sektor informal dan pergaulan . beberapa contoh bisnis bidang komunikasi adalah pelatihan prestasi dan public relation, MC, retorika, pelatihan periklanan, produk publikasi organisasi dll.

Persaingan di bidang bisnis komunikasi sangat ketat, dimana hanya beberapa saja yang bisa bertahan lebih dari 5 tahun di kota Malang. Beberapa faktor yang memerlukan keberlanjutan maka tersebut adalah faktor manajemen, SDM, serta menjaga dan memperluas relasi, yang barangkali sulit bagi para pemula untuk memulai usaha pelatihan di bidang komunikasi.

Mahasiswa jurusan ilmu komunikasi UMM memiliki potensi-potensi praktis di bidang komunikasi. Mereka telah memiliki bekal kompetensi dan didukung oleh wadahwadah yang dimiliki UMM seperti PR Club, jurnalistik fotografi dan majalah mahasiswa, oleh karena itu mereka layak untuk diarahkan sebagai wirausahawan.

Pelaksanaan magang mahasiswa berlangsung selama 2 bulan di INDOPURELS oleh 4 orang mahasiswa. Tahap pelaksanaan magang meliputi : Rekruitmen dan selain mahasiswa calon peserta, pembekalan, pemberangkatan, pemagangan 2 bulan, monitoring dan evaluasi, penjemputan.
\end{abstract}

1) 2) Staf Pengajar Fakultas Sosial dan Pemerintahan UMM 
Jurnal Dedikasi Volume 7, Mei 2010

\section{A. Pendahuluan}

\section{Analisis Situasi}

Bidang Komunikasi telah menjadi ladang bisnis bagi para wirausahawan. Hal ini mempertimbangkan pentingnya keterampilan komunikasi dalam kehidupan sehari-hari, baik dalam sektor informal seperti keluarga dan pergaulan maupun disektor formal seperti untuk keperluan karir, dan bisnis. Meskipun hampir semua orang bisa berkomunikasi, namun terampil berkomunikasi secara efektif tidak dimiliki oleh semua orang. Adanya gap kebutuhan komunikasi dan kemampuan berkomunikasi inilah yang sering melatar belakangi lahirnya ide-ide kewirausahaan di bidang komunikasi. Beberapa contoh bisnis bidang komunikasi antara lain Pelatihan Presentasi, Pelatihan Public Relations, MC, dan Retorika, Pelatihan Menulis dan Jurnalistik, Pelatihan Periklanan, produksi publikasi organisasi, dsb.

Membuka pelatihan-pelatihan bidang komunikasi tersebut, sampai sekarang masih menjamur di Malang dan kota-kota lain. Selain luasnya pasar, juga cukup layak diperhitungkan sebagai sumber income. Sebagai contoh, pelatihan komunikasi termurah bisa mematok harga 100 rb dan termahal di Malang bisa sampai 5 juta satu paket. Dengan rata-rata peserta rninimal 15 orang, dan maksimal 75 orang. Tetapi dari sekian banyak lembaga pelatihan, hanya beberapa saja yang bisa bertahan lebih dari 5 tahun secara sehat, baik dari sisi finansial maupun manajemen. Beberapa hal yang menjadi faktor keberlanjutan usaha tersebut adalah faktor manajemen, SDM, serta menjaga dan memperluas relasi. Hal inilah yang seringkali sulit bagi para pemula untuk memulai usaha pelatihan di bidang komunikasi.

Sementara itu, mahasiswa Jurusan Ilmu Komunikasi ternyata memiliki potensipotensi praktis di bidang komunikasi. Saat ini melalui wadah PR Club, Jumalistik Fotografi, dan Majalah Mahasiswa, sebenamya rnereka layak untuk diarahkan sebagai wirausahawan. Alasannya bekal kompetensi sudah ada. Tinggal dibekali lag dengan kemampuan profesional dalam mengelola sebuah lembaga yang profit. Kegiatan-kegiatan PR Club, JUFOC, dan Majalah Mahasiswa sejauh ini masih terbatas pada lingkungan internal kampus. Mereka mengadakan event-event kreatif untuk Jurusan, fakultas, dan Unit-unit yang ada di kampus, dan juga pelatihan-pelatihan yang masih terbatas untuk para anggota dan mahasiswa.

Jurusan Ilmu Komunikasi Universitas Muhammadiyah Malang setiap tahunnya melepas sarjana baru tidak kurang dari 180 orang. Para alumninya harus menunggu pekerjaan yang sesuai dengan bidangnya. Hasil evaluasi Jurusan menunjukkan ratarata masa tunggu masih cukup lama, yaitu sekitar 5 bulan. Itupun masih menyerap sekitar $60 \%$ lulusannya. Kondisi tersebut dikarenakan rata-rata alumni ingin mendapatkan pekerjaan disebuah perusahaan atau industri komunikasi yang besar. Jarang yang tergerak untuk berwirausaha di bidang jasa pelatihan komunikasi sesuai dengan keterampilan yang mereka miliki, padahal ketika mereka menjadi mahasiswa dan bergabung dalam PR Club, JUFOC, dan Majalah Mahasiswa mengadakan pelatihan sudah bukan pekerjaan asing. 
Frida.Penguatan Pengetahuan dan Manajerial.

Berdasarkan analisis situasi di atas, maka perlu adanya penguatan pengetahuan dan keterampilan usaha jasa kornunikasi melalui adaptasi bisnis di sebuah lembaga jasa komunikasi INDOPURELS (Indonesia Public Relations), MALANG untuk para mahasiswa Jurusan Ilmu Komunikasi semester VIII.

\section{Tujuan}

Tujuan Magang Kewirausahaan (MKU) di INDOPURELS, MALANG adalah:

1. Mahasiswa dapat memperoleh pengalaman kerja praktis di bidang usaha jasa komunikasi.

2. Meningkatkan pengetahuan kewirausahaan dikalangan mahasiswa dalam bidang jasa komunikasi.

3. Memacu mahasiswa setelah lulus kuliah merencanakan usaha jasa komunikasi.

4. Mahasiswa dapat mengidentifikasi masalah, perumusan, dan pemecahan masalah dalam hal mendesain produk, pemasaran, dan manajemen usaha jasa komunikasi.

\section{Justifikasi Pemilihan INDOPURELS Sebagai Tempat Magang}

INDOPURELS, Malang adalah lembaga yang bergerak di bidang Sumber Daya Manusia (SDM), berdiri pada tahun 1991. INDOPURELS didirikan oleh sekelompok anak muda dibawah pembinaan pakar komunikasi dan administrasi Djanalis Djanaid - seorang Dosen tetap FIA Unibraw, Wakil Ketua Dewan Penasehat KADIN Jatim, Tim Instruktur Pelatihan
Kewirausahaan \& Kepimpinan, Direktur Indopurels \& Indogement Nara Sumber pada berbagai Seminar. Salah satu Team Instruktur Seminar. Salah satu Team Instruktur Pelatihan Kepimpinan \& Kewirausahaan di luar negeri (Thailand, Mesir, dan Perancis).

Secara singkat INDOPURELS di Jl. Watu Gong 41 Malang, Jawa Timur, dipilih sebagai tempat magang bagi mahasiswa Jurusan Ilmu Komunikasi Fakultas Ilmu Sosial dan Ilmu Politik Universitas Muhammadiyah Malang memiliki kriteria seperti dalam Tabel 1.

Tabel I:

Kriteria Pemilihan Tempat Magang

\begin{tabular}{|c|c|c|}
\hline NO & KRITERIA PEMILIHAN & POTENSI MITRA \\
\hline 1. & Ptoduk jasa PR \& komunikasi & $\begin{array}{l}\text { 1. Pelatihan public relations, Ms, dan } \\
\text { retorika } \\
\text { 2. Pelatihan jumalistik } \\
\text { 3. Pelatihan teknik prentasi } \\
\text { 4. Pelatihan manajemen press clipping } \\
\text { 5. Pelatihan service excelent } \\
\text { 6. Pelatihan kewrirausahaan }\end{array}$ \\
\hline 2. & Kondisipemasaran & $\begin{array}{l}\text { Perusahaan-perusahaan menengah ke atas } \\
\text { membutuhkan keterampilan praktis dan } \\
\text { mankajerial dibidang PR \& komunikasi } \\
\text { bagi para staf dan manager } \\
\end{array}$ \\
\hline 3. & Jangkauan pemasaran & Selunuh Indonesia dan regional Asia \\
\hline 4. & Harga jual jasa & Bersaing \\
\hline 5. & Sumber dava: & \\
\hline & a. manusia & Berpengalaman (profesional) \\
\hline & b. sarana prasarana & Tersedia memadai \\
\hline & c. dana & Modal sendiri dan kemitraan \\
\hline 6. & Kondisimanajemen & Pola manajemen profesional \\
\hline 7. & Kondisil lavanan jasa & $\begin{array}{l}\text { Reguler, paket, dan sesuai permintaan (in } \\
\text { house training) }\end{array}$ \\
\hline 8. & Fasilitas komunikasi & Web, telepon, dan fax \\
\hline 9. & lokasi & Mudah dijangkau peserta magan \\
\hline
\end{tabular}


Jurnal Dedikasi Volume 7, Mei 2010

\begin{abstract}
Manajemen INDOPURELS
mempunyai konsep "JARUM

HIPODERMIK” yang apabila diterapkan pada suatu organisasi /perusahaan akan memiliki 4 (empat) fungsi, yaitu :
\end{abstract}

1. Meningkatkan semangat dan kreatifitas kerja

2. Mampu memiliki daya tahan organisasi terhadap setiap goncangan

3. Memiliki kemampuan untuk membasmi penyakit organisasi (mis. Kemalasan, ketidakjujuran, dan lain-lain)

4. Mengatur hubungan baik antar individu, unit, baik kedalam maupun keluar organisasi

Visi INDOPURELS adalah menjadi lembaga pengembangan sumber daya manusia (SDM) yang paling dipercaya di Indonesia, bagi perusahaan yang menjadikan SDM-nya sebagai asetnya yang paling utama dan berharga. INDOPURELS bercita-cita menjadi lembaga yang menghimpun para profesional di bidang SDM yang memiliki integritas dan loyalitas diri yang tinggi dan yang menjalankan darmanya di bidang SDM, serta memperoleh kepuasan. Adapun Misinya meliputi:

1. Kepada usaha Melaksanakan kegiatan utama berupa pelatihan, lokakarya, seminar serta kegiatankegiatan lainnya sebagai pendukung kegiatan utama di atas.

2. Kepada SDM Menciptakan budaya "konsentrasi dalam bekerja untuk mencapai prestasi yang tinggi, pengembangan diri, kepuasan kerja dan kesejahteraan”.
3. Kepada pelanggan memberikan pelayanan yang melebihi harapan pelanggan.

4. Kepada share-holder dan mitra kerja Memberikan keuntungan financial dan kebanggaan.

5. Kepada supplier Memberikan keuntungan financial dan kebanggaan.

6. Kepada masyarakat ikut serta meningkatkan mutu SDM Indonesia.

Sampai sekarang INDOPURELS telah memiliki 60 produk pelatihan yang sudah disosialisasikan dan telah mengadakan pelatihan sebanyak 514 angkatan baik dalam bentuk in-house training maupun public course. Sementara khusus produk INDOPURELS di bidang jasa PR dan Komunikasi adalah

1. Pelatihan Public Relations, MS, \& Retorika ( 17 modul)

2. Pelatihan Jurnalistik (15 modul)

3. Pclatihan Teknik Prentasi (4 rnoclul)

4. Pelatihan Manajemen Press Clipping (3 modul)

5. Pelatihan scrvice Excelent (8 modul)

6. Pelatihan kewirausahaan (6 modul)

produk-produk di atas sangat mernungkinkan untuk dipecah lagi menjadi produk-produk yang independent sehingga dapat menyesuaikan cost yang harus dikeluarkan oleh para peminat pangsa pasar produk jasa ini adalah para praktisi public relations dan para praktisi khususnya manajer non public relations. Para peserta 
Frida.Penguatan Pengetahuan dan Manajerial.

dapat mengikuti pelatihan dalam bentuk public course maupun in house training.

\section{B. Pelaksanaan Program \\ 1.Tahapan Pelaksanaan}

Tercapainya kesepakatan kerja sama dengan mitra tempat magang

Setelah melakukan lobbi dengan direktur Indopurels, maka dicapai kesepakatan pihak INDOPURELS menerima magang mahasiswa Jurusan Ilmu Komunikasi sebanyak 4 (empat) orang dengan masa magang pertama dua bulan. Pihak INDOPURELS bersedia membimbing mahasiswa selama magang dan memberi pengetahuan serta pengalaman kerja sesuai dengan kegiatan-kegiatan yang dilaksanakan oleh INDOPURELS.

Pemilihan INDOPURELS sebagai tempat magang selain telah dikemukakan sebelumnya adalah juga untuk memberi contoh kepada peserta magang (mahasiswa) bahwa memulai sebuah "bisnis" tidak harus memiliki suatu tempat yang elit. INDOPURELS diawali dengan sebuah ide untuk menampung semangat pemuda (mahasiswa). Awalnya hanya menempati sebuah garasi rumah drs. Djanalis Djanaid di Jl. Watu Gong pada tahun 1990. Bukan di jalan utarna atau pinggir jalan raya yang ramai, melainkan di sebuah perumahan. Plang nama atau identitas juga tidak mencolok seperti nampak dalam foto. Saat ini INDOPURELS telah menempati bangunan di atas garasi dengan 3 ruangan: Ruang kerja, Ruang untuk Gudang, dan Ruang Manajemen dan Ruang Rekruitmen.

\section{Rekuitmen dan Seleksi}

\section{Mahasiswa Calon Peserta Magang}

Pada tahapan ini, dosen pengusul program MKU mengumumkan informasi program kepada mahasiswa Jurusan Ilmu Komunikasi melalui poster yang ditempel di papan pengumuman. Informasi ini dipasang selama bulan April-Mei 2009. Jumlah peminat program ini ada 8 mahasiswa. Dengan mempertimbangkan tahun angkatan dan keahliannya maka ditentukan kriteria sbb:

- Angkatan 2006 yang terdaftar sebagai mahasiswa aktif

- Telah menempuh beban SKS sebanyak 120 SKS

- Memiliki keterampilan di bidang web site atau penulisan atau pelayanan dasar atau announcer (kriteria ini sesuai dengan kebutuhan INDOPURELS saat itu). Pemilihan keterampilan menulis, liputan, web design \& program, dan fotografi diperlukan karena setelah pembicaraan awal dan observasi, kami melihat ada peluang untuk memberi konstribusi aktif pada INDOPURELS dengan mengelola web site INDOPURELS, disamping tidak melupakan peluangpeluang belajar bisnis khususnya penyelenggaraan event Pelatihan Jasa dibidang komunikasi.

Akhirnya ditentukan 4 orang mahasiswa dan pada bulan Mei 2009 dilakukan pemanggilan kepada pelamar yang lulus administratif dan interview. Mahasiswa- mahasiswa tersebut adalah: 
Jurnal Dedikasi Volume 7, Mei 2010

1. Nama : Achmad Fajar

Maulana

NIM : 06220211

Asal : Gresik

Keahlian : : Web Design and

Program

2. Nama

NIM

Asal

Keahlian

Liputan

3. Nama

NIM

Asal

Keahlian

4. Nama

$\begin{array}{ll} & \text { Ardianty } \\ \text { NIM } & : 06220368 \\ \text { Asal } & \text { : Gresik } \\ \text { Keahlian } & : \text { Penulisan }\end{array}$

\section{Pembekalan Kepada Mahasiswa \\ Calom Peserta Magang}

Sebelum peserta ke tempat magang, dilakukan pembekalan selama satu bulan dengan materi Manajemen Event, Teknik Lobi dan Negosiasi, dan Kepribadian Wirausaha. Selain itu mahasiswa juga dibekali dengan pinformasi tentang profil INDOPURELS dan gambaran kerja di INDOPURELS.

\section{Pemberangkatan Peserta Magang}

Peserta magang diberangkatkan pada tanggal 6 Juli 2009 dengan diantar oleh pembimbing dan diterima oleh Direktur INDOPURELS, Juniardi, SH. Pada awal pertemuan dilakukan perkenalan dengan seluruh tim INDOPURELS yang terdiri dari Manajer Keuangan, Manajer Event, Manajer Rumah Tangga dan Manajer Marketing.

\section{Pemagangan Selama 2 Bulan}

Selama dua bulan magang, peserta dilibatkan dalam kegiatan-kegiatan short course INDOPURELS maupun pekerjaan harian selayaknya para pegawai. Bahkan peserta dapat kesempatan untuk berdiskusi dengan pemilik, dan para pengelola INDOPURELS. Tidak jarang peserta diberi kesempatan mengikuti acara-acara sosial dan komunitas para pengelola, seperti dalam mengelola Travel, Merintis Usaha WellMart minimarket Sayur, dan kajian-kajian yang diselenggarakan oleh organisasi profesi seperti PERHUMAS dan Jaringan Bisnis Syariah.

Selain dilibatkan dalam kegiatan INDOPURELS, peserta magang juga diberi kepercayaan penuh untuk mengelola situs atau company web INDOPURELS. Keputusan untuk mengelola situs tersebut adalah perkembangan yang tidak direncanakan. Latar belakang situasinya adalah para peserta dan dosen pembimbing melihat situs INDOPURELS sudah sangat lama tidak di up date. Setelah menelusuri ternyata hal tarsebut dikarenakan tidak ada team works yang ada yang kompeten mengelola.

\section{Rencana Bisnis Dan Analisa Usaha}

\section{Rencana Bisnis}

Pengelolaan website pada akhirnya memberi inspirasi peserta magang untuk merintis bisnis jasa pengelolaan website suatu organisasi atau lembaga. Berikut ini merupakan 
Pengetahuan dan Manajerial.

analisis SWOT bisnis pengelolaan website INDOPURELS:

Sebagai perusahaan yang besar dengan sekitar 6000 orang alumni, INDOPURELS memerlukan media yang efektif dan efisien untuk berkomunikasi dengan alumni dan klien. Peluncuran website adalah solusi yang tepat, karena selain dapa mencakup seluruh wilayah global, memudahkan orang untuk berkomunikasi dengan INDOPLJRELS mengingat fasilitas yang disediakan sangat interaktif, Dibandingkan dengan media publikasi konvensional, websiter tergolog murah dari segi pembiayaan, namun dari sisi pengelolaan tergolong rumit dan memerlukan keahlian khusus dalam hal teknis. Disinilah INDOPRELS memerlukan satu tim khusus pengelola website.

Setelah disepakati bahwa peserta Magang Kewira Usahaan menjadi pengelola website INDOPURELS, maka dibuatkan organizing sbb:

1. WebMaster

- Tugas

B e r t a ng gung jawab atas segala sesuatu yang berhubungan dengan hosting dan scripting

- Kualifikasi: HTML Master, ASP Master, PHP Master, Java
Master, CMS

Master

2. Content Administrator

- Tugas :

B e r t ang gung jawab atas segala sesuatu yang berkaitan dengan muatan berita website, termasuk news reporting.

- Kualifikasi: Menguasai CMS, mampu menulis berita, menguasai teknik fotografi

3. Design Layout

- Tugas

B e r t a n g g ung jawab atas segala sesuatu yang berhubungan dengan rancangan layout website

- Kualifikasi: $\mathrm{M}$ a s t e ring p hot os hop, menguasai CMS

Dengan pengorganisasi seperti tersebut di atas, peserta Magang telah mampu mengelola website INDOPURELS selama dua bulan. Data teknis selanjutnya yang berhubungan dengan launching website INDOPURELS karya peserta magang dapat dilihat di lampiran laporan ini. Saat ini sedmg direncanakan tahap selanjutnya untuk kontrak pertama dengan INDOPURELS sebagai klien 
Jurnal Dedikasi Volume 7, Mei 2010

pertama bagi Kelompok Bisnis yang terbentuk karena adanya Magang Kewirausahaan di Bidang Komunikasi ini.

Kepuasan pihak INDOPURELS terhadap hasil kerja peserta magang ditunjukkan dengan kepercayaan yang penuh pada peserta magang untuk mengelola website. Peserta magang selalu diberi kesempatan mengikuti kegiatan-kegiatan INDOPURELS dalam rangka melakukan liputan khusus untuk materi website. Bagi mahasiswa, kompensasi finansial yang diperoleh juga memuaskan, terlebih dengan kompensasi pengalaman yang luar biasa. Peserta magang belajar bagaimana menghadapi klien dengan bijaksana namun negosiatif. Peserta magang juga merasakan pengaruh semangatkewirausahaan dari para pengelola INDOPURELS.

Pengalaman mengelola website dan kepercayaan penuh dari INDOPURELS memberi inspirasi terbentuknya Kelompok Bisnis pengelolaan website bagi, suatu lembaga.

\section{Analisa Usaha}

Kelompok Bisnis yang terbentuk akan mencari klien, yaitu perusahaan atau lembaga-lembaga yang telah memiliki website, namun website tersebut belum dikelola dengan baik. Salah satu dan yang utama indikasi pengelolaan website yang tidak baik adalah website tersebut tidak pernah melakukan upload selama tiga bulan lebih. pemilihan calon klien yaitu perusahaan atau lembaga yang telah memiliki website akan memudahkan Kelompok Bisnis karena tidak perlu lagi meyakinkan akan pentingnya media website bagi suatu komunikasi organisasi. Asumsinya, perusahaan atau lembaga yang telah memiliki website adalah perusahaan atau lembaga yang telah menyadari pentingnya website.

Kelebihan website dibandingkan dengan media konvensional adalah biaya yang murah. Berdasarkan pengalaman mengelola website INDOPURELS berikut ini adalah kalkulasi biaya pengelolaan website yang harus dikeluarkan oleh sebuah perusahaan:

a. Biaya menggunakan domain khusus korporasi Rp. 450.000/th

b. Biaya operasional untuk liputan, posting Rp. $2.400 .000 / b l n$ dengan up date seminggu $3 \mathrm{X}$ c. Biaya scripting dan design Rp. $1.000 .000 /$ paket
Total
Rp. 3.850 .000 Total

Jadi sebuah perusahaan hanya memerlukan biaya Rp. 3.850 .000 untuk menggunakan jasa layanan Kelompok Bisnis ini selama satu bulan (5 minggu). Dari biaya tersebut, maka yang bisa dikelola menjadi "omzet" Kelompok Bisnis adalah Rp.1.400.000/bulan per website. Apabila $10 \%$ masuk investasi, atau Rp. 340 ribu disisihkan untuk investasi, maka sharing penghasilan tiap orang adalah Rp. 765.000/ bulan. Lebih jelasnya lihat tabel berikut: 
Frida.Penguatan Pengetahuan dan Manajerial.

Kalkulasi untuk mengelola satu website:

\begin{tabular}{|c|l|c|r|}
\hline No & \multicolumn{1}{|c|}{ Keterangan } & Pemasukan & Pengeluaran \\
\hline 1 & Biaya paket & 3.850 .000 & \\
\hline 2 & Biaya domain & & 450.000 \\
\hline 3 & $\begin{array}{l}\text { Investasi usaha 10\% setelah dikurangi } \\
\text { biaya domain }\end{array}$ & & 240.000 \\
\hline 4 & $\begin{array}{l}\text { Penghasilan 4 orang pengelola Rp } \\
600.000\end{array}$ & & 2.400 .000 \\
\hline 5 & Biaya designer dan lay out & 3.850 .000 & \\
\hline
\end{tabular}

Dengan demikian dalam satu tahun, Kelompok Bisnis ini bisa memiliki omzet sebesar Rp. $1.000 .000+$ (Rp. 2.400.000 X 12): Rp. 9.800 .000 (dua puluh sembilan juta delapan ratus ribu rupiah) pertahun. Omzet tersebut akan di share untuk investasi Rp. 240.000 X 12: Rp. 2.880.000/tahun. Sisanya adalah penghasilan untuk para pengelola.

Rancangan kerja dan biaya tersebut ternyata hanya menghabiskan waktu 3 jam perhari setiap pengelola. Apabila jam kerja perhari bisa ditingkatkan menjadi 9 jam, maka Kelompok Bisnis ini secara optimal bisa mengelola tiga website sekaligus. Sehingga total omzet bisa mencapai Rp. 89.400.000/ tahun, yang dishare untuk investasi sebesar Rp. 8.640.000/tahun dan penghasilan per orang Rp. 1.800.000/bulan.

namun ternyata bisa, menghasilkan suatu kegiatan yang bernilai ekonomi tinggi. Apa yang dilakukan INDOPURELS adalah contohnya.

Semangat yang tinggi, komitmen untuk menjadi pribadi yang mandiri, pandai dan cerdik membaca peluang kebutuhan masyarakat, serta berdisiplin tinggi adalah tauladan jiwa wirausaha yang bisa diserap oleh peserta magang dari personil-penonil di INDOPURELS. Tidak hanya itu, keterbukaan dan penerimaan INDOPURELS kepada peserta magang merupakan sikap pendukung bagi peserta magang untuk selalu bisa dilibatkan dalam setiap kegiatan INDOPURELS. Pengalaman menghadapi banyak orang terutama kaum eksekutif perusahaan merupakan pelajaran yang sangat berharga.

\section{Penutup}

Program Magang Kewirausahaan merupakan program yang sangat positif dan efektif dalam mendorong mahasiswa memikirkan dan bertindak untuk berbisnis. Tidak jarang masyarakat memiliki kreativitas yang kelihatannya rendah, 
Jurnal Dedikasi Volume 7, Mei 2010 